\title{
Turnover of Lipoprotein (a) in Man
}

\author{
Franz Krempler, Gerhard M. Kostner, Klaus Bolzano, \\ and Friedrich SANdhofer, First Department of Medicine, \\ Landeskrankenanstalten, A-5020 Salzburg, Austria, \\ and Institute of Medical Biochemistry, University of Graz, \\ A-8010 Graz, Austria
}

A B S T R A C T An elevated concentration of lipoprotein (a) $[\mathrm{Lp}(\mathrm{a})]$ in the serum has been considered a risk factor for coronary heart disease by various investigators. In the present study, the turnover of $\mathrm{Lp}(\mathrm{a})$ was investigated in nine individuals with serum $\mathrm{Lp}$ (a) levels ranging from 1 to $68 \mathrm{mg} / 100 \mathrm{ml}$. After intravenous injection of radioiodinated $L p(a)$, the radioactivity time-curve of the serum and the specific activitity time-curves of the isolated $\mathrm{Lp}(\mathrm{a})$ and $\mathrm{Lp}(\mathrm{a})$ apolipoproteins were measured for $14 \mathrm{~d}$. More than $97 \%$ of the label was found in the protein moiety of Lp(a). During the entire study period, the serum radioactivity remained with $\mathrm{Lp}(\mathrm{a})$, only insignificant amounts of radioactivity were detectable in other lipoprotein fractions. The serum radioactivity timecurves and the specific activity time-curves of the isolated $\mathrm{Lp}(\mathrm{a})$ and $\mathrm{Lp}(\mathrm{a})$ apolipoproteins were identical.

The kinetic parameters of $L p(a)$ turnover were calculated in terms of a two-compartment model. $76.5 \pm 5.1 \%$ (mean $\pm 1 \mathrm{SD}$ ) of total $\mathrm{Lp}(\mathrm{a})$ was contained in the intravascular space. The biological half-life of $L p(a)$ was $3.32 \pm 0.52 \mathrm{~d}$, the fractional catabolic rate (FCR) was $0.306 \pm 0.054 / \mathrm{d}$, and the rate of synthesis was $5.00 \pm 3.37 \mathrm{mg} / \mathrm{kg} / \mathrm{d}$. A positive correlation was found between serum concentration and synthetic rate of $\mathrm{Lp}(\mathrm{a})$ apoprotein. No relationship could be demonstrated between serum level and FCR of $L p(a)$.

The results of this study indicate that $L p(a)$ is not converted to other serum lipoproteins. From the correlations between serum concentration and kinetic parameters of $\mathrm{Lp}(\mathrm{a})$ it is concluded that an elevated $\mathrm{Lp}$ (a) level is the consequence of an increased $\mathrm{Lp}(\mathrm{a})$ apoprotein synthesis.

\section{INTRODUCTION}

When the lipoprotein (a) $[\mathrm{Lp}(\mathrm{a})]^{1}$ was first described (1), it was considered a genetic variant of low density

\footnotetext{
Received for publication 15 August 1979 and in revised form 11 December 1979.

${ }^{1}$ Abbreviations used in this paper: FCR, fractional catabolic rate; HDL, high density lipoprotein; LDL, low density lipoprotein; Lp(a), lipoprotein (a); VLDL, very low density lipoprotein.
}

lipoprotein (LDL). Other studies, however, have demonstrated that $L p(a)$ is a separate lipoprotein, although it exhibits some physicochemical and immunological properties that are similar to those of LDL. The lipid composition of these two lipoproteins, as determined by several investigators $(2-4)$, is nearly identical. On the other hand, $\mathrm{Lp}$ (a) shows a severalfold higher content of hexose, hexosamine, and sialic acid than LDL (5). This may explain why Lp(a) migrates faster than LDL on agarose gel or cellulose acetate and, therefore, forms a separate band between $\beta$ - and pre- $\beta$-lipoproteins, which was named "pre$\beta_{1}$ " band (6-8). The main apolipoprotein of $\operatorname{Lp}(\mathrm{a})$ has been found to be identical with apolipoprotein $B$ of LDL $(5,9)$. Lp(a), however, contains an additional, specific $L p(a)$ antigen, which is dissociable from apolipoprotein B by several agents $(5,10)$. In contrast to apolipoprotein $B$, the specific $L p(a)$ antigen is soluble in $6 \mathrm{M}$ urea (11). By ultracentrifugation $\mathrm{Lp}(\mathrm{a})$ is found in the fraction of density $1.055-1.110 \mathrm{~g} / \mathrm{ml}$ (11), which is somewhat higher than the density of LDL and overlaps that of LDL and high density lipoproteins (HDL).

It is well documented that $\mathrm{Lp}(\mathrm{a})$ is present in the serum of all individuals with apolipoprotein B, although in different individuals its serum level may vary to a considerable degree $(12,13) . \mathrm{Lp}(\mathrm{a})$ has gained extensive clinical interest since a relationship between the concentration of $L p(a)$ in the serum and the occurrence of coronary heart disease has been postulated by several investigators $(6,7,13,14) . \mathrm{Lp}(\mathrm{a})$ has also been demonstrated by immunohistochemical methods in the intima of human arteries (15).

Although Lp(a) might play an important role in the development of atherosclerotic vascular lesions, only scarce information is available about the metabolism of this lipoprotein. In a previous study the half-life of radiomethylated $\mathrm{Lp}(\mathrm{a})$ has been determined (16). It has been shown recently that $L p(a)$ is not a metabolic product of other apolipoprotein B-containing lipoproteins (17). Therefore it has been suggested that $\mathrm{Lp}(\mathrm{a})$ is synthesized as a separate lipoprotein. No information, however, exists about the regulation of 
the serum concentration and the catabolic pathway of $\operatorname{Lp}(\mathrm{a})$.

\section{METHODS}

Subjects. The clinical data of the subjects are given in Table I. None of them revealed thyroid, renal, or hepatic dysfunction or hyperglycemia. All individuals were checked for $L p(a)$ by immunodiffusion with specific antisera to $L p(a)$ (see below). All subjects were "Lp(a)-positive" except subject No. 1. In this individual no $\operatorname{Lp}(\mathrm{a})$ could be detected by immunodiffusion and no measurable $\mathrm{Lp}(\mathrm{a})$ concentration was found using Laurell's one-dimensional immunoelectrophoresis (see below). All individuals were hospitalized during the investigation. They were kept on a "normal" hospital diet containing $45-50 \%$ of total calories as carbohydrates, $30-35 \%$ fat, and $15-20 \%$ protein. None of them received any treatment (except thiazide diuretics) known to influence lipid metabolism. Body weight and the serum concentration of $\mathrm{Lp}(\mathrm{a})$, total cholesterol, and triglyceride were constant throughout the study (Table I). Potassium iodide $(3 \times 60 \mathrm{mg}$ daily) was administered to each individual beginning $3 \mathrm{~d}$ before the study and continuing throughout the entire experiment. Informed consent to the study was obtained from each subject.

Separation and iodination of $L p(a) . \quad L p(a)$ was isolated according to the method of Ehnholm et al. (18). After an overnight fast, plasma was obtained by plasmapheresis using citrate-dextrose as anticoagulant and dialysed against $0.15 \mathrm{M}$ $\mathrm{NaCl}$ containing $\mathrm{Na}_{2}$ EDTA $(1 \mathrm{mg} / \mathrm{ml})$ and $\mathrm{NaN}_{3}(1 \mathrm{mg} / \mathrm{ml})$. The plasma was then brought to a solution density of 1.055 $\mathrm{g} / \mathrm{ml}$ by addition of solid $\mathrm{NaCl}$ and centrifuged at $42,000 \mathrm{rpm}$ for $22 \mathrm{~h}$. The densities of the sera were measured at $15^{\circ} \mathrm{C}$ with a calculating digital density meter (Anton Paar K.G., Graz, Austria). All ultracentrifugal procedures were performed in a Beckman L5-50 centrifuge with a Ti 50.2 rotor at $15^{\circ} \mathrm{C}$ (Beckman Instruments, Inc., Fullerton, Calif.). The top fraction was removed by tube slicing, the lower fraction was brought to a density of $1.110 \mathrm{~g} / \mathrm{ml}$ by addition of solid $\mathrm{NaCl}$ and then centrifuged at $44.000 \mathrm{rpm}$ for $22 \mathrm{~h}$. The top fraction, which contained the lipoproteins with densities of $1.055-1.110 \mathrm{~g} / \mathrm{ml}$, was concentrated to a volume of about $4 \mathrm{ml}$ by dialysis against a $30 \%$ solution of polyethyleneglycol (mol wt, 20.000) containing $\mathrm{Na}_{2}$ EDTA $\left(1 \mathrm{mg} / \mathrm{ml}\right.$ ) and $\mathrm{NaN}_{3}$ $(1 \mathrm{mg} / \mathrm{ml}) . \mathrm{Lp}(\mathrm{a})$ was then separated from other lipoproteins by filtration on an agarose column $(0.9 \times 100 \mathrm{~cm})$ using Bio Gel A-5m (Bio-Rad Laboratories, Richmond, Calif.). Elution of the lipoproteins was carried out at room temperature with $0.15 \mathrm{M} \mathrm{NaCl}$ containing $\mathrm{Na}_{2}$ EDTA $(1 \mathrm{mg} / \mathrm{ml})$ and $\mathrm{NaN}_{3}(1 \mathrm{mg} / \mathrm{ml}), \mathrm{pH}$ adjusted to 8.5 by addition of $\mathrm{NH}_{4} \mathrm{OH}$. The elution profile is shown in Fig. 1. The peaks were identified by immunodiffusion using monospecific antisera $(16,17,19)$. The $L p(a)$ peak was further characterized by its electrophoretic mobility on agarose (single band between $\beta$ - and pre- $\beta$-lipoproteins of normal serum), immunoelectrophoresis [precipitation line at identical position with anti$\mathrm{Lp}(\mathrm{a})$ and anti-Lp B], and chemical composition as described recently $(16,17)$. To avoid contamination of $L p(a)$ with $L D L$, only the front portion of the $\mathrm{Lp}(\mathrm{a})$ peak was used for iodination and analytical procedures. The $\mathrm{Lp}(\mathrm{a})$ eluted from the column was concentrated to $\sim 1 \mathrm{mg}$ protein $/ \mathrm{ml}$ by dialysis against polyethyleneglycol and then dialysed against glycine buffer, $\mathrm{pH}$ 10. The isolated and concentrated $\mathrm{Lp}(\mathrm{a})$ consisted of a clear solution. By electrophoresis in agarose gel, $95 \%$ of the material migrated as a narrow band in the position between $\beta$ - and pre- $\beta$-lipoproteins of normal serum. Iodination with ${ }^{125}$ I (The Radiochemical Centre, Amersham, England) was performed according to McFarlane (20) as modified by Bilheimer et al. (21). Free iodine was removed by filtration on Sephadex G-25 and subsequent dialysis against $0.15 \mathrm{M}$ $\mathrm{NaCl}$ with several bath changes. Isolation and iodination of $\mathrm{Lp}$ (a) took $4 \mathrm{~d}$. Labeled $\mathrm{Lp}$ (a) was injected on the morning of the 5 th $\mathrm{d}$ after plasmapheresis.

TABLE I

Clinical Data of the Subjects

\begin{tabular}{|c|c|c|c|c|c|c|c|c|c|}
\hline Subject & Sex & Age & Weight* & Height & $\begin{array}{l}\text { Serum } \\
\operatorname{Lp}(a)^{*}\end{array}$ & $\begin{array}{c}\text { Serum } \\
\text { cholesterol* }\end{array}$ & $\begin{array}{c}\text { Serum } \\
\text { triglycerides* }\end{array}$ & Diagnosis & Medication \\
\hline & & $y r$ & $k g$ & $\mathrm{~cm}$ & $m g / 100) m l$ & $\mathrm{mg} / 100 \mathrm{ml}$ & $m g / 100 \mathrm{ml}$ & & \\
\hline 1 & Male & 21 & $63.2 \pm 0.1$ & 174 & $<1$ & $227 \pm 18$ & $176 \pm 16$ & Bronchitis $\downarrow$ & - \\
\hline 2 & Male & 43 & $67.0 \pm 0.1$ & 167 & $3 \pm 0.9$ & $192 \pm 10$ & $154 \pm 12$ & Normal & - \\
\hline 3 & Male & 57 & $77.7 \pm 0.1$ & 179 & $44 \pm 4.9$ & $225 \pm 13$ & $130 \pm 15$ & Emphysema & - \\
\hline 4 & Male & 70 & $75.2 \pm 0.0$ & 172 & $41 \pm 5.1$ & $196 \pm 15$ & $142 \pm 17$ & Normal & - \\
\hline 5 & Male & 66 & $62.2 \pm 0.1$ & 166 & $71 \pm 6.2$ & $212 \pm 14$ & $112 \pm 10$ & Hypertension & $\begin{array}{l}\text { Amiloride, hydro- } \\
\text { chlorothiazide }\end{array}$ \\
\hline 6 & Male & 52 & $74.5 \pm 0.2$ & 178 & $35 \pm 2.6$ & $231 \pm 21$ & $123 \pm 19$ & Angina pectoris & Nitrate \\
\hline 7 & Male & 57 & $70.0 \pm 0.1$ & 172 & $28 \pm 1.9$ & $243 \pm 19$ & $98 \pm 9$ & Hypertension & $\begin{array}{l}\text { Amiloride, hydro- } \\
\text { chlorothiazide }\end{array}$ \\
\hline 8 & Male & 21 & $65.0 \pm 0.0$ & 163 & $68 \pm 4.3$ & $195 \pm 11$ & $158 \pm 14$ & Normal & - \\
\hline 9 & Male & 59 & $75.5 \pm 0.1$ & 176 & $56 \pm 3.8$ & $205 \pm 16$ & $102 \pm 16$ & Angina pectoris & Nitrate \\
\hline
\end{tabular}

* Mean \pm 1 SD.

f Patient was recovered at the time of the study. 


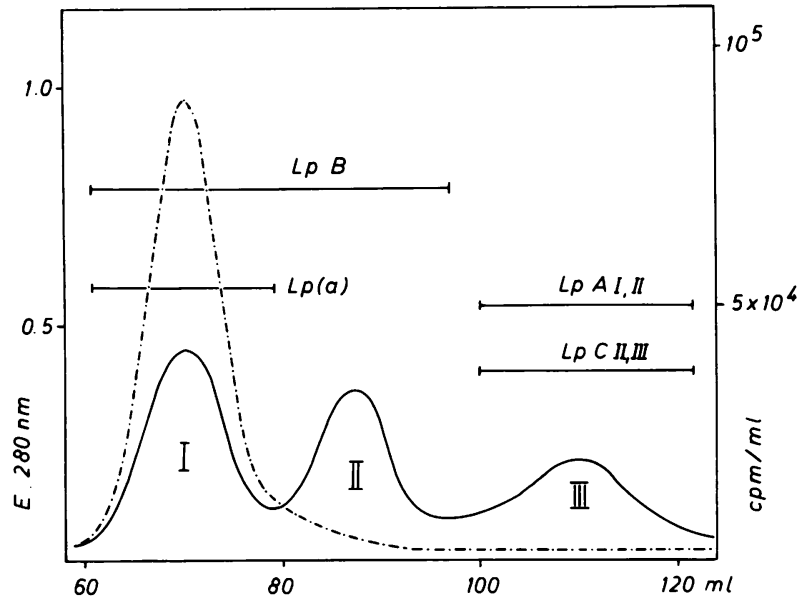

FIGURE 1 Elution profile of the lipoproteins of density $1.055-1.110 \mathrm{~g} / \mathrm{ml}$ on Bio-Gel A-5m. The sample was taken $24 \mathrm{~h}$ after the intravenous injection of labeled $\mathrm{Lp}(\mathrm{a})$. extinction at $280 \mathrm{~nm} ; \cdot \cdot \cdot-\cdot-\cdot$, radioactivity $(\mathrm{cpm} / \mathrm{ml})$. The immunological reactivities of the eluted fractions against antibodies to $\mathrm{Lp}(\mathrm{a})$, apolipoprotein A I and A II, B, C II, and C III are indicated. Peak I represents $L p(a)$, peak II lipoprotein B (part of the serum LDL), and peak III part of the HDL. Void volume $60 \mathrm{ml}$.

Characterization of the labeled $L p(a)$. Labeled $L p(a)$ showed the same electrophoretic mobility on agarose gel and identical immunoreactive behavior as unlabeled $\mathrm{Lp}(\mathrm{a})$. When labeled and unlabeled $\mathrm{Lp}(\mathrm{a})$ were mixed and applied to an agarose column (Bio-Gel A-5m), the labeled $\mathrm{Lp}(\mathrm{a})$ eluted in the same fraction as the unlabeled $L p(a) .0 .5-3 \%$ of the radioactivity in $\mathrm{Lp}(\mathrm{a})$ was found in the lipid moiety after extraction with chloroform:methanol (2:1) (22). 14-17\% of the radioactivity in $L p(a)$ was found in the "soluble" and $80-85 \%$ in the "insoluble" apolipoproteins (see below).

Study protocol. Labeled $\operatorname{Lp}(\mathrm{a})$ was sterilized by passage through a Millipore filter $(0.45 \mathrm{~nm}$; Millipore Corp., Bedford, Mass.) before the injection. After an overnight fast, 50-70 $\mu \mathrm{Ci}$ labeled $\mathrm{Lp}(\mathrm{a})$ was injected intravenously. Autologous $\mathrm{Lp}(\mathrm{a})$ was injected in subjects 3-6 and 9. Subjects 1 and 2 received labeled $\mathrm{Lp}(\mathrm{a})$, which was obtained from subject 5 , and subjects 7 and 8 received labeled $L p(a)$ from subject 9 . Venous blood was drawn 10 min after the injection of the labeled $L p(a)$ and at various intervals during the lst $d$ and then every morning for up to $14 \mathrm{~d}$. Two subjects were studied for $21 \mathrm{~d}$. In these samples the radioactivity of the serum was measured. In subjects $3-6,50 \mathrm{ml}$ of blood was obtained $10 \mathrm{~min}, 6 \mathrm{~h}$, and $24 \mathrm{~h}$ after the injection of labeled $\mathrm{Lp}(\mathrm{a})$, and then at different intervals throughout the study, as shown in Fig. 3. In these samples, $L p(a)$, very low density lipoproteins (VLDL) and LDL were isolated and the radioactivity in these lipoproteins and in the fraction with a density $>1.110 \mathrm{~g} / \mathrm{ml}$ was estimated as follows: Serum was brought to a density of $1.055 \mathrm{~g} / \mathrm{ml}$ by addition of solid $\mathrm{NaCl}$ and centrifuged for $22 \mathrm{~h}$ at $42,000 \mathrm{rpm}$. The top fraction, which contained VLDL and the bulk of LDL, was collected by tube slicing, dialyzed against saline with a density of $1.006 \mathrm{~g} / \mathrm{ml}$, and then centrifuged for $20 \mathrm{~h}$ at 42,000 $\mathrm{rpm}$. The top fraction, was removed by slicing the tube. From the bottom fraction LDL was purified from contaminating $\mathrm{Lp}$ (a) by gel filtration on Bio-Gel A-5m as described above. The fractions containing VLDL, the purified LDL, the purified HDL, which eluted from the agarose column (Fig. 1), and the density $>1.110 \mathrm{~g} / \mathrm{ml}$ fraction were checked for radioactivity. $\mathrm{Lp}(\mathrm{a})$ was isolated and purified by ultracentrifugation and gel filtration as described above. In the purified $\mathrm{Lp}(\mathrm{a})$, protein content and radioactivity were measured. In addition, part of the purified $L p(a)$ was dialyzed against distilled water, lyophilized, and the lipids removed with diethylether:ethanol $(1: 3, \mathrm{vol} / \mathrm{vol})$. From the resultant apolipoproteins, the soluble apolipoproteins were obtained by extraction with $6 \mathrm{M}$ urea. The insoluble apolipoproteins were washed several times with $6 \mathrm{M}$ urea. Removal of soluble apolipoproteins was considered complete when no radioactivity could be detected in the urea solution. The remaining insoluble apolipoproteins were solubilized by addition of sodium dodecyl sulfate. The protein content and the radioactivity in both the soluble and insoluble apolipoproteins were measured to obtain the specific activity. The mean ratio of the specific activities in soluble and insoluble apolipoproteins was $2: 3$ and remained constant throughout the study.

In three subjects (Nos. 7-9) 24-h urine specimens were collected for calculation of the fractional catabolic rate of $\mathrm{Lp}(\mathrm{a})$ from the urinary radioactivity excretion. $\mathrm{KI}, \mathrm{NaHSO}_{3}$, and $\mathrm{NaOH}$ was added to the urine samples as a preservative (23).

Chemical and immunological analysis. Protein concentrations were measured according to Lowry et al. (24), total cholesterol by the Lieberman Burchard kit from Boehringer Mannheim GmbH, Mannheim, West Germany, and triglycerides according to Eggstein and Kreutz (25). Agarose electrophoresis was carried out in $1 \%$ agarose gel using $0.05 \mathrm{M}$ barbital buffer, $\mathrm{pH}$ 8.2. Immunodiffusion was performed in $1 \%$ agarose using monospecific antisera (19). Quantitation of serum $\mathrm{Lp}(\mathrm{a})$ was carried out by Laurell's electroimmunoassay (rocket electrophoresis) (26) on glass plates $(7 \times 7 \mathrm{~cm})$ in $1 \%$ agarose gels, $0.05 \mathrm{M}$ barbital buffer, $\mathrm{pH} 8.2$. The antibody was monospecific for the $\mathrm{Lp}(\mathrm{a})$ antigen and identical with the specimen described earlier $(16,17,19)$; it gave no crossreactivity with apo $\mathrm{B}$ or any other apolipoprotein of the $\mathrm{A}-\mathrm{F}$ class. 0.05 or $0.1 \mathrm{ml}$ of antiserum was used per $6 \mathrm{ml}$ of agarose and per plate. Each plate was used for 14 analyses and contained three highly purified $L p(a)$ standards of different concentrations as well as $1-3$ reference $L p(a)-$ positive sera, which had been standardized and kept at $4^{\circ} \mathrm{C}$ for $<1$ mo. The purified $\mathrm{Lp}(\mathrm{a})$ standard was prepared as described above and was homogenous according to the following criteria: single band in agarose gel electrophoresis, no reaction with antibodies other than anti- $\mathrm{Lp}(\mathrm{a})$ and anti$\mathrm{Lp} B$, chemical composition characteristic for $\operatorname{Lp}(\mathrm{a})(11,16$, 17). The concentration of the standard was measured gravimetrically by determination of the residual weight after equilibration dialysis (coefficient of variation was $<1 \%$ ). Electrophoresis was carried out at a field strength of $5 \mathrm{~V} / \mathrm{cm}$ for $3 \mathrm{~h}$ at $15^{\circ} \mathrm{C}$ in $0.05 \mathrm{M}$ barbital buffer, $\mathrm{pH} 8.2$. The plates were rinsed after electrophoresis in $0.15 \mathrm{M}$ saline for $2-4 \mathrm{~h}$, dryed, and stained with Coomassie Blue R 250. The evaluation of the $L p(a)$ concentrations was performed by comparing the rocket area (height times width at half height) of the samples with that of highly purified standards. The relationship between the rocket area $\left(\mathrm{mm}^{2}\right)$ and protein concentration was linear from $5-25 \mathrm{mg} \mathrm{Lp}(\mathrm{a}) / 100 \mathrm{ml}$ in the low antibody containing gels and from $20-60 \mathrm{mg} \mathrm{Lp}(\mathrm{a}) / 100 \mathrm{ml}$ in the high antibody containing gels. Samples of higher concentrations were diluted accordingly. The electroimmunoassay worked with a day-to-day coefficient of variation of $<5 \%$.

Calculations. The fraction of the injected dose of radioactivity remaining in the plasma was plotted semilogarithmically against time (Fig. 2). The fractional catabolic rate (FCR = fraction of intravascular $\mathrm{Lp}(\mathrm{a})$ catabolized per day) was calculated according to the method described by Matthews (27): $\mathrm{FCR}=1 /\left(\mathrm{C}_{1} / \mathrm{b}_{1}+\mathrm{C}_{2} / \mathrm{b}_{2}\right)$, where $\mathrm{C}_{1}, \mathrm{C}_{2}=$ intercepts of 


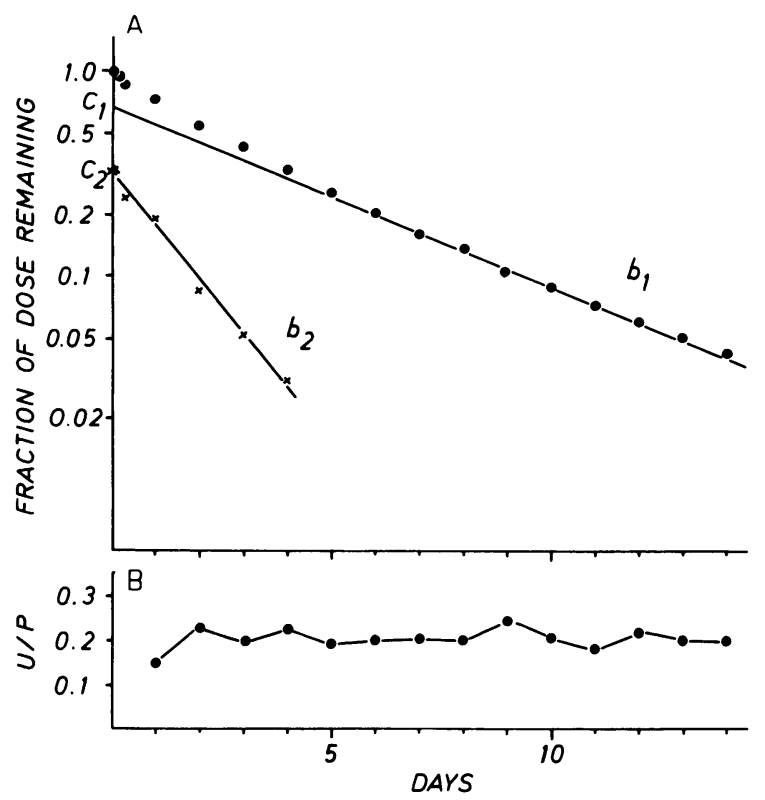

Figure 2 Serum die-away curve and urine/plasma (U/P) radioactivity ratios of subject 9 after intravenous injection of ${ }^{125} \mathrm{I}-\mathrm{Lp}(\mathrm{a})$. (A) The fraction of injected radioactivity remaining in the serum is plotted semilogarithmically against time. The first exponential $\left(b_{1}\right)$ was calculated from the terminal log-linear portion of the decay curve. The second exponential $\left(b_{2}\right)$ was obtained by subtraction of the first exponential from the serum die-away curve. $C_{1}$ and $C_{2}$ are the intercepts of the first and second exponential with the vertical axis. (B) Daily $\mathrm{U} / \mathrm{P}$ ratios are shown.

the first and second exponential with the vertical axis and $b_{1}, b_{2}=$ slopes of the first and second exponential (Fig. 2). The proportion of the total pool of $\mathrm{Lp}(\mathrm{a})$ that was in the intravascular space was calculated using the formula (27):

$$
\text { percent intravascular }=\frac{\left(\frac{C_{1}}{b_{1}}+\frac{C_{2}}{b_{2}}\right)^{2}}{\frac{C_{1}}{\left(b_{1}\right)^{2}}+\frac{C_{2}}{\left(b_{2}\right)^{2}}}
$$

Under steady-state conditions, the rate of synthesis of $\mathrm{Lp}(\mathrm{a})$ is equal to its absolute rate of catabolism. The absolute rate of synthesis or catabolism (milligram per day) of $\mathrm{Lp}(\mathrm{a})$ was calculated as the product of FCR times plasma volume times $\mathrm{Lp}$ (a) concentration. The plasma volume was estimated using Edelman's formula (28). FCR was also calculated as the ratio of the daily urinary excretion of radioactivity to the total amount of radioactivity in the plasma (29). Statistical calculations were performed using standard methods (30).

\section{RESULTS}

Throughout the study, $>96 \%$ of the total radioactivity in the serum remained with $\operatorname{Lp}(\mathrm{a})$. Less than $0.05 \%$ of the serum radioactivity was found in VLDL. In LDL, HDL, and in the salt volume eluting from the column, only traces of radioactivity were detectable after purification on Bio-Gel A-5m. In the unpurified density fraction $>1.110 \mathrm{~g} / \mathrm{ml}$, a total amount of $<3 \%$ of the serum radioactivity was found. Presumably, this was due to contamination with labeled $L p(a)$, in that the radioactivity in purified HDL was negligible. Under the assumption that the labeled apolipoprotein has not been altered by iodination, these findings seem to indicate that no conversion of serum $\mathrm{Lp}(\mathrm{a})$ to other serum lipoproteins or exchange of apolipoproteins between $\mathrm{Lp}(\mathrm{a})$ and other lipoproteins occurred.

In four subjects the specific activities of the isolated intact $L p(a)$ molecule and of the soluble and the insoluble apolipoproteins were determined at different times of the study as shown in Fig. 3. These values are expressed as fraction of the specific activities at 10 min after the injection of labeled $L p(a)$. The values obtained for the whole $\mathrm{Lp}(\mathrm{a})$ molecule, the soluble and the insoluble apolipoproteins were compared with the corresponding values of the serum radioactivity decay curve. The mean difference between the values of the intact $L p(a)$ and the corresponding values of the serum radioactivity decay curve was $+0.3 \pm 4.8 \%($ mean $\pm 1 \mathrm{SD})$, between the soluble apolipoproteins and the serum radioactivity was $+0.5 \pm 7.5 \%$, and between the insoluble apolipoproteins and the serum radioactivity was $-3.0 \pm 6.5 \%$. This shows that the decay of the specific activity of the whole $L p(a)$ molecule and of the individual apolipoproteins was practically identical with the decay of the serum radioactivity. The percentage of radioactivity in the lipid moiety of the $\mathrm{Lp}(\mathrm{a})$ molecule showed some decline during the first days of the experiment, but was too low to influence the calculation of the kinetic parameters at any time of the study.

Therefore, it was permissible to calculate the kinetic parameters of the $\mathrm{Lp}(\mathrm{a})$ turnover from the serum radioactivity-time curves. The concentration of $L p(a)$ in the serum was determined by immunoelectrophoresis repeatedly from the beginning until the end of the study and showed little variation as indicated in Table I. In subjects 3-6, the serum level of $L p(a)$ apolipoprotein could also be calculated from the radioactivity of the serum and the specific activity of the isolated $\mathrm{Lp}(\mathrm{a})$, since $>96 \%$ of the radioactivity in the serum was associated with the protein moiety of $L p(a)$. Also from this calculation, a constant $\mathrm{Lp}(\mathrm{a})$ concentration was found in each case. The constancy of the $L p(a)$ concentration during the study period was considered to reflect a steady state in $\operatorname{Lp}(\mathrm{a})$ turnover.

Fig. 2 shows a representative serum radioactivity time-curve. In all cases, the curves showed an initial rapid decline merging with a log-linear portion about $4 \mathrm{~d}$ after the injection of the labeled $\mathrm{Lp}(\mathrm{a})$. Since the radioactivity decay curves could always be resolved into two exponentials by curve peeling (Fig. 2), the kinetic parameters were calculated in terms of a two- 

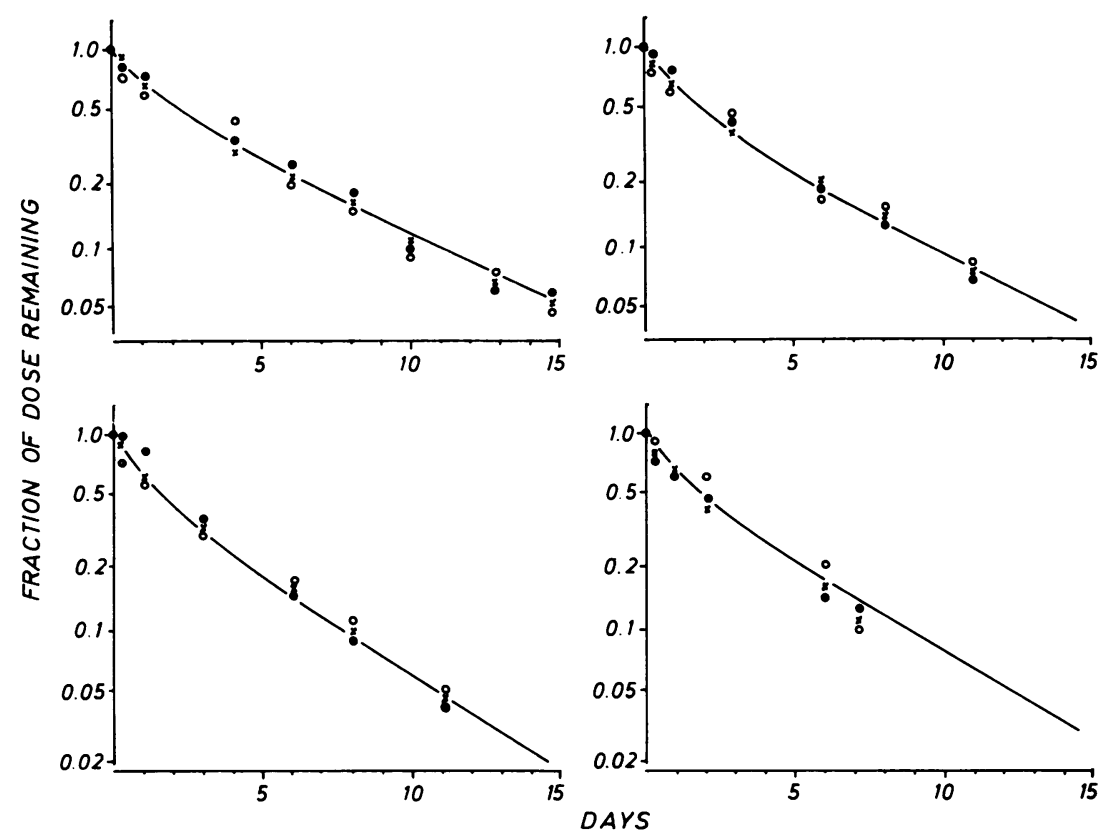

FIgure 3 Die-away curve of the serum radioactivity (__ ) and decay of the specific activities of the isolated intact $\mathrm{Lp}(\mathrm{a})(\times)$, the soluble $(O)$ and insoluble $(O)$ apolipoproteins of $\mathrm{Lp}(\mathrm{a})$ after intravenous injection of ${ }^{125} \mathrm{I}-\mathrm{Lp}(\mathrm{a})$ in subjects $5,4,6$, and 3 . The decay of the whole $\mathrm{Lp}(\mathrm{a})$ molecule and of its individual apolipoproteins closely follows the die-away curve of the serum radioactivity.

compartment model (27). The regression line of the first exponential was calculated from the values obtained from the 5th to last day of the study. In two cases the radioactivity time-curve was followed for $21 \mathrm{~d}$ and the decay curves could also be resolved into two exponentials. The kinetic parameters were identical when calculated from the values of the first 14 or $21 \mathrm{~d}$.

The kinetic parameters of $\mathrm{Lp}(\mathrm{a})$ are presented in Table II. In subjects 7-9, the FCR was also calculated from the urine/plasma radioactivity ratio. This method can be applied for the estimation of

TABLE II

Kinetic Parameters of $L p(a)$ Turnover

\begin{tabular}{|c|c|c|c|c|c|c|}
\hline $\begin{array}{c}\text { Subject } \\
\text { No. }\end{array}$ & $\begin{array}{l}\text { Serum } \\
\text { Lp(a) }\end{array}$ & $\begin{array}{l}\text { Half-life of * } \\
\text { second } \\
\text { exponential }\end{array}$ & $\begin{array}{l}\text { Half-life of * } \\
\text { first } \\
\text { exponential }\end{array}$ & FC:R & $\begin{array}{c}\text { Distribution } \\
\text { of } L p(a)\end{array}$ & $\begin{array}{l}\text { Rate of } \\
\text { synthesis }\end{array}$ \\
\hline & $m g / l(\%) m l$ & $d$ & $d$ & Fraction of i.t. poold & $\begin{array}{l}\text { \% intra- } \\
\text { cascular }\end{array}$ & $m g / k g / d$ \\
\hline 1 & $<1$ & 0.72 & 3.05 & 0.343 & 70.7 & 0.16 \\
\hline 2 & 3 & 0.63 & 2.64 & 0.392 & 73.8 & 0.51 \\
\hline 3 & 44 & 0.57 & 3.04 & 0.308 & 77.9 & 5.89 \\
\hline 4 & 41 & 1.11 & 3.71 & 0.258 & 82.6 & 5.03 \\
\hline 5 & 71 & 0.44 & 3.91 & 0.236 & 78.8 & 7.97 \\
\hline 6 & 35 & 0.71 & 2.90 & 0.336 & 76.9 & 5.11 \\
\hline 7 & 28 & 0.96 & 4.20 & $0.272(0.248 \pm 0.017 \ddagger)$ & 67.9 & 3.31 \\
\hline 8 & 68 & 1.10 & 3.02 & $0.350(0.335 \pm 0.020 \ddagger)$ & 73.8 & 10.75 \\
\hline 9 & 56 & 1.13 & 3.45 & $0.257(0.228 \pm 0.043 \ddagger)$ & 86.0 & 6.26 \\
\hline Mean & & 0.82 & 3.32 & 0.306 & 76.5 & 5.00 \\
\hline SD & & 0.26 & 0.52 & 0.054 & 5.1 & 3.37 \\
\hline
\end{tabular}

* Half-life of the first $\left(b_{1}\right)$ and second $\left(b_{2}\right)$ exponential of the serum radioactivity time-curve.

$\$$ Values calculated from urine/plasma radioactivity ratio, mean \pm 1 SD of the values from day 2 to 14 .

$\$$ Units for $L p(a)$ synthesis refer to the entire $L p(a)$ molecule. 


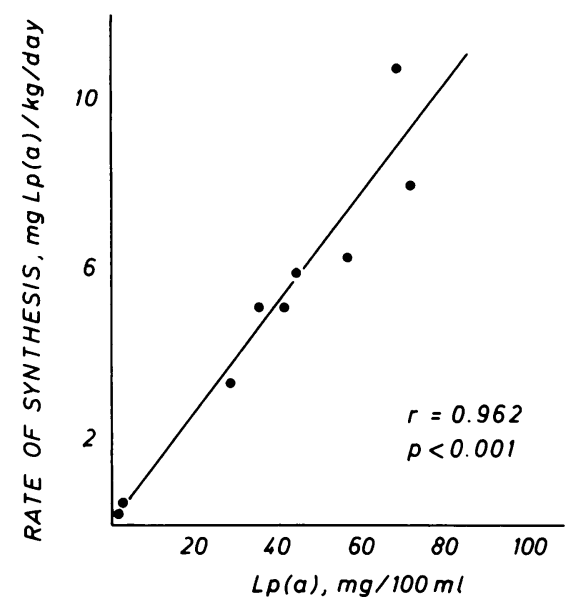

FIgURE 4 Relationship between $\mathrm{Lp}(\mathrm{a})$ concentration in the serum and rate of synthesis of $L p(a)$.

$\mathrm{Lp}(\mathrm{a})$ turnover, because practically all the radioactivity of the serum was contained in $L p(a)$ over the entire study period. The values obtained by this method were in close agreement with the values for FCR obtained from the die-away curve of the serum radioactivity (Table II).

A positive correlation was found between the concentration of $\mathrm{Lp}(\mathrm{a})$ in the serum and the absolute rate of synthesis of serum $L p(a)$ apoproteins (Fig. 4). There appeared to be a tendency toward an inverse relationship between the serum level of $L p(a)$ and FCR, but this correlation could not be proven statistically (Fig. 5). No relationship existed between the serum concentration and half-lives of $L p(a)$ in the serum.

The mean FCR of $L p(a)$ was somewhat lower in the five subjects who received autologous $L p(a)$ as com-

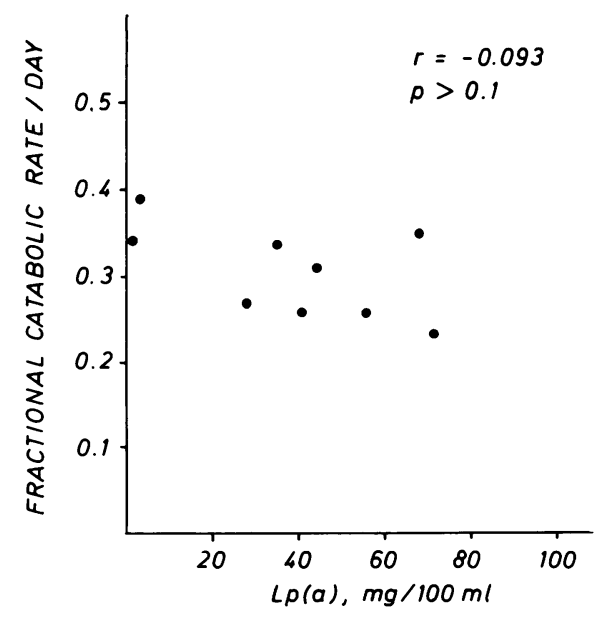

FIGURE 5 Relationship between $L p(a)$ concentration in the serum and FCR of $\mathrm{Lp}(\mathrm{a})$. pared with the four subjects who received nonautologous $\mathrm{Lp}(\mathrm{a})$. This difference, however, was not statistically significant.

\section{DISCUSSION}

After the intravenous injection of labeled $L p(a)$ only insignificant amounts of radioactivity were detectable in lipoproteins other than $\mathrm{Lp}(\mathrm{a})$ during the study period. The specific activity time-curves for the isolated whole $\mathrm{Lp}(\mathrm{a})$ molecule, the soluble and the insoluble $L p(a)$ apolipoproteins, and the radioactivity time-curve of the serum were identical. Apparently, $\mathrm{Lp}(\mathrm{a})$ is not converted to another lipoprotein and no exchange of apolipoproteins between $L p(a)$ and other lipoproteins takes place. $L p(a)$ appears to leave the plasma pool as an intact particle as suggested in a recent study (16). Other experiments, in which labeled VLDL has been injected to $\mathrm{Lp}(\mathrm{a})$-positive individuals, have shown that $L p(a)$ is not derived from the catabolism of other apolipoprotein B-containing lipoproteins (17). Therefore, it is suggested that $\mathrm{Lp}(\mathrm{a})$ is synthesized and metabolized independently of other plasma lipoproteins. This conclusion could explain the findings of others that the serum level of $L p(a)$ is not influenced by various dietary manipulations that are known to cause considerable changes in the plasma concentrations of other lipoproteins (13).

The half-life of $L p(a)$ has already been estimated using reductive alkylation as method of labeling (16). Due to the low radioactivity of $L p(a)$ in this former study, the radioactivity time-curve of $L p(a)$ could be followed for only $4 \mathrm{~d}$. Therefore, only the initial rapid decline of the whole die-away curve could be observed and hence a monoexponential plasma decay of $L p(a)$ was assumed (16). This explains that the half-lives obtained in this earlier study are shorter than those calculated in terms of a two-pool model in this study. During the first $4 \mathrm{~d}$ after the injection of labeled $\mathrm{Lp}(\mathrm{a})$, the decay of radiomethylated and radioiodinated $\mathrm{Lp}(\mathrm{a})$ is similar.

The kinetic parameters of $L p(a)$ obtained in this study are very similar to those of LDL in normal subjects as found by others. The mean FCR of $\mathrm{Lp}(\mathrm{a})$ is $\sim 20-30 \%$ lower and the average percentage of the total $\mathrm{Lp}(\mathrm{a})$ pool that was in the circulation is $15-20 \%$ higher than the corresponding values found for LDL by Langer et al. (31), Simons et al. (32), and Sigurdsson et al. (33). The mean values for FCR and for the distribution of $\mathrm{Lp}(\mathrm{a})$ between intravascular and extravascular space were practically identical with those found for LDL by Packard et al. (34). The biological half-life of $L p(a)$ was slightly longer than that of LDL as reported by Langer et al. (31) and Simons et al. (32), and slightly shorter than that of LDL found by Sigurdsson et al. (33) and Packard et al. (34). Apparently, there 
are not only immunological and chemical similarities between LDL and Lp(a). From the comparison of the kinetic parameters of these two lipoproteins one may suggest that these two lipoproteins also appear to be acted upon by similar catabolic mechanisms. To prove this assumption kinetic studies of LDL and Lp(a) in patients with familiar hypercholesterolemia would be of interest.

It has been reported by others that the concentrations of $L p(a)$ vary in a wide range among the individuals of a population $(13,18,35)$. The $\mathrm{Lp}(\mathrm{a})$ level in a single individual, however, remains remarkably constant $(13,18)$. Principally, the concentration of $L p(a)$ in the serum is dependent on the rate of synthesis and the FCR of the lipoprotein. The individuals in this study also showed very different serum $L p(a)$ levels. Their FCR, however, varied to a much lesser degree and there was no relationship between the concentration and FCR of $\mathrm{Lp}(\mathrm{a})$. On the other hand, a highly significant correlation was found between the serum concentration and the absolute synthetic rate of $L p(a)$. Therefore, it is concluded that the mechanism that is responsible for an elevated concentration of $L p(a)$ in the serum of these subjects is not a defective catabolism but an increased synthesis of $L p(a)$. It should be stated that the studies of this paper were performed in males. Until now no information is available on the $\mathrm{Lp}(\mathrm{a})$ turnover in females.

Studies with ${ }^{125}$ I-labeled LDL in patients with an elevated LDL concentration indicated a defect of LDL catabolism in these subjects. In homozygote and heterozygote patients with familial hyperbetalipoproteinemia, a reduced FCR of LDL was found (31-34). A marked increase in the synthesis of LDL in the homozygotes has also been reported (32). In this study, the $L p(a)$ concentration was not dependent on the FCR of $\mathrm{Lp}(\mathrm{a})$. However, the possibility that a defective catabolism, as found in familial hyperbetalipoproteinemia, is responsible for an increased $\mathrm{Lp}$ (a) level cannot be excluded. Until now, no information is available about the site and regulation of $L p(a)$ synthesis or catabolism.

\section{ACKNOWLEDGMENTS}

The technical assistance of Miss H. Talman and Miss E. Meisl is gratefully acknowledged.

This study was supported by Fonds zur Förderung der Wissenschaftlichen Forschung, Project No. 4018.

\section{REFERENCES}

1. Berg, K. 1963. A new serum type system in man-the Lp system. Acta Pathol. Microbiol. Scand. 59: 369-382.

2. Simons, K., C. Ehnholm, O. Renkonen, and B. Bloth. 1970. Characterization of the $\mathrm{Lp}(\mathrm{a})$ lipoprotein in human plasma. Acta Pathol. Microbiol. Scand. Sect. B. Microbiol. Immunol. 78: 459-466.
3. Vogelberg, K. H., G. Uterman, and F. A. Gries. 1973. Zur Differenzierung des $L p(a)$ Lipoproteins mit Hilfe der Agargel-Elektrophorese. Z. Klin. Chem. Klin. Biochem. 11: $291-296$.

4. Jürgens, G., and G. M. Kostner. 1975. Studies on the structure of the $\mathrm{Lp}(\mathrm{a})$ lipoprotein. Isolation and partial characterization of the $\mathrm{Lp}(\mathrm{a})$ specific antigen. Immunogenetics. 1: 560-574.

5. Ehnholm, C., H. Garoff, O. Renkonen, and K. Simons. 1972. Protein and carbohydrate composition of $\mathrm{Lp}(\mathrm{a})$ lipoproteins from human plasma. Biochemistry. 11: 3229-3232.

6. Dahlen, G., K. Berg, U. Ramberg, and A. Tamm. 1974. $\mathrm{Lp}(\mathrm{a})$ lipoprotein and pre- $\beta_{1}$-lipoprotein in young adults. Acta Med. Scand. 196: 327-331.

7. Berg, K., G. Dahlen, and M. H. Frick. 1974. Lp(a) lipoprotein and pre- $\beta_{1}$-lipoproteins in patients with coronary heart disease. Clin. Genet. 6: 230-235.

8. Albers, J. J., V. G. Cabana, G. R. Warnik, and W. R. Hazzard. 1975. Lp(a) lipoprotein: Relationship to sinking pre- $\beta$-lipoprotein, hyperlipoproteinemia and apolipoprotein B. Metab. Clin. Exp. 24: 1047-1054.

9. Albers, J. J., C. H. Chen, and F. Aladjem. 1972. Human serum lipoproteins. Evidence for three classes of lipoproteins in $\mathrm{S}_{\mathrm{f}}$ 0-2. Biochemistry. 11: 57-63.

10. Uterman, G., K. Lipp, and H. Wiegandt. 1972. Studies on the $L p(a)$ lipoprotein of human serum. IV. The disaggregation of the $\mathrm{Lp}(\mathrm{a})$ liponrotein. Humangenetik. 14: $142-150$.

11. Kostner, G. M. 1976. Lp(a) lipoproteins and the genetic polymorphisms of lipoprotein B. In Low Density Lipoproteins. C. E. Day and R. S. Levy, editors. Plenum Publishing Corp., New York. 229-269.

12. Albers, J. J., and W. R. Hazzard. 1974. Immunochemical quantification of human plasma Lp(a) lipoprotein. Lipids. 9: 15-26.

13. Albers, J. J., J. L. Adolphson, and W. R. Hazzard. 1977. Radioimmunoassay of human plasma $\mathrm{Lp}(\mathrm{a})$ lipoprotein. J. Lipid Res. 18: 331-338.

14. Dahlen, G., C. Ericson, C. Furberg, L. Lundkvist, and K. Svärdsudd. 1972. Studies on extra pre- $\beta$ lipoprotein fraction. Acta Med. Scand. Suppl. 531: 1-29.

15. Walton, K. W. 1974. Identification of lipoproteins involved in human atherosclerosis. In Atherosclerosis III. G. Schettler and A. Weizel, editors. Springer-Verlag, Berlin. 93-95.

16. Krempler, F., G. Kostner, K. Bolzano, and F. Sandhofer. 1978. Studies on the metabolism of the lipoprotein $\mathrm{Lp}(\mathrm{a})$ in man. Atherosclerosis. 30: 57-65.

17. Krempler, F., G. Kostner, K. Bolzano, and F. Sandhofer. 1979. Lipoprotein (a) is not a metabolic product of other lipoproteins containing apolipoprotein B. Biochim. Biophys. Acta. 575: 63-70.

18. Ehnholm, C., H. Garoff, K. Simons, and H. Aro. 1971. Purification and quantitation of the human plasma lipoprotein carrying the $\mathrm{Lp}(\mathrm{a})$ antigen. Biochim. Biophys. Acta. 236: 431-439.

19. Kostner, G. M., J. R. Patsch, S. Sailer, H. Braunsteiner, and A. Holasek. 1974. Polypeptide distribution of the main lipoprotein density classes separated from human plasma by rate zonal ultracentrifugation. Eur. J. Biochem. 45: 611-621.

20. McFarlane, A. S. 1958. Efficient trace-labelling of proteins with iodine. Nature (Lond.). 182: 53.

21. Bilheimer, D. W., S. Eisenberg, and R. I. Levy. 1972. The metabolism of very low density lipoprotein proteins. I. Preliminary in vitro and in vivo observations. Biochim. Biophys. Acta. 260: 212-221. 
22. Folch, J. M., M. Lees, and G. H. Sloane-Stanley. 1957. A simple method for the isolation and purification of total lipids from animal tissues. J. Biol. Chem. 226: 497-509.

23. Steinfeld, J. L., R. R. Paton, A. L. Flick, R. A. Milch, and F. E. Beach. 1957. Distribution and degradation of human serum albumin labeled with $\mathrm{I}^{131}$ by different techniques. Ann. N. Y. Acad. Sci. 70: 109-121.

24. Lowry, O. H., N. J. Rosebrough, A. L. Farr, and R. J. Randall. 1951. Protein measurement with the Folin phenol reagent. J. Biol. Chem. 193: 265-275.

25. Eggstein, M., and F. H. Kreutz. 1966. Eine neue Bestimmung der Neutralfette im Blutserum und Gewebe. I. Mitteilung. Prinzip, Durchführung und Besprechung der Methode. Klin. Wochenschr. 44: 262-265.

26. Laurell, C. B. 1972. Electroimmunoassay. Scand. J. Clin. Lab. Invest. Suppl. 124: 21-37.

27. Matthews, C. M. E. 1957. The theory of tracer experiments with ${ }^{131}$ I-labelled plasma proteins. Phys. Med. Biol. 2: 36-53.

28. Edelman, I. S., and J. Leibman. 1959. Anatomy of body water and electrolytes. Am. J. Med. 27: 256-277.

29. Berson, S. A., and R. S. Yalow. 1957. Distribution and metabolism of $\mathrm{I}^{131}$ labeled proteins in man. Fed. Proc. 16: $13 \mathrm{~S}-18 \mathrm{~S}$.
30. Snedecor, G. W., and W. C. Cochran. 1967. Statistical Methods. The Iowa State University Press, Ames, Iowa. Sixth edition.

31. Langer, T., W. Strober, and R. I. Levy. 1972. The metabolism of low density lipoproteins in familial type II hyperlipoproteinemia. J. Clin. Invest. 51: 1528-1536.

32. Simons, L. A., D. Reichl, N. B. Myant, and M. Mancini. 1975. The metabolism of the apoprotein of plasma low density lipoprotein in familial hyperbetalipoproteinemia in the homozygous form. Atherosclerosis. 21: 283-298.

33. Sigurdsson, G., A. Nicoll, and B. Lewis. 1976. The metabolism of low density lipoprotein in endogenous hypertriglyceridemia. Eur. J. Clin. Invest. 6: 151-158.

34. Packard, C. J., J. L. H. C. Third, J. Shepherd, A. R. Lorimer, H. G. Morgan, and T. D. V. Lawrie. 1976. Low density lipoprotein metabolism in a family of familial hypercholesterolemic patients. Metab. Clin. Exp. 25: 995- 1006.

35. Schultz, J. S., D. C. Schreffler, C. F. Singer, and N. R. Harvie. 1974. The genetics of the Lp antigen. Its quantitation and distribution in a sample population. Ann. Hum. Genet. 38: 39-46. 